\title{
CIĄŻA W ROGU SZCZĄTKOWYM MACICY
}

\section{PREGNANCY IN A RUDIMENTARY HORN OF THE UTERUS}

\author{
Katedra i Zakład Fizjologii Pomorskiego Uniwersytetu Medycznego w Szczecinie \\ al. Powstańców Wlkp. 72, 70-111 Szczecin \\ Kierownik: prof. dr hab. n. med. Mariusz Z. Ratajczak
}

\begin{abstract}
Summary
Pregnancy in a rudimentary horn of the uterus, a rare form of ectopic pregnancy, develops in women affected by developmental abnormalities of the growth and fusion of the Müllerian paramesonephric ducts. In the Polish population, this problem affects $4-8$ women per year. The paper analyzes the problems that are associated with pregnancy developing in the rudimentary horn. Due to the continuous progress in medical sciences, maternal mortality has been almost completely eliminated in this form of ectopic pregnancy, while neonatal survival has risen to about $20 \%$. Further developments in medicine allow us to be moderately optimistic about further improvement of the treatment's statistics.

K e y w o r d s: rudimentary horn pregnancy - ectopic pregnancy - Müllerian anomalies.
\end{abstract}

\section{Streszczenie}

Ciąża w rogu szczątkowym macicy to rodzaj rzadko występującej ciąży ektopowej, rozwijającej się u kobiet, u których w okresie ich rozwoju embrionalnego doszło do nieprawidłowości w procesie wzrostu i zespolenia przewodów przyśródnerczowych Müllera. W populacji polskiej problem ten dotyczyć może 4-8 kobiet rocznie. $\mathrm{W}$ pracy dokonano analizy problemów, jakie wiążą się z ciążą rozwijającą się w rogu szczątkowym macicy. W efekcie postępu w naukach medycznych praktycznie zlikwidowano umieralność wśród matek w tej postaci ciąży ektopowej, a przeżywalność noworodków podniesiono do ok. $20 \%$. Rozwój w medycynie pozwala z umiarkowanym optymizmem patrzeć na dalszą poprawę statystyk leczenia.
H a s ł a: ciąża w rogu szczątkowym macicy - ciąża ektopowa-zaburzenia müllerowskie.

\section{Wstęp}

Ektopowa lokalizacja to jedno z najczęściej występujących powikłań wczesnej ciąży, w którym dochodzi do zagnieżdżenia się blastocysty poza endometrium jamy macicy. Obecnie ryzyko tego powikłania stanowi 1-2\% wszystkich ciąż. 95-97\% ciąż ektopowych rozwija się w jajowodach, głównie w ich częściach bańkowych, w których zwykle dochodzi do zapłodnienia [1]. Pozostały odsetek obejmuje ciąże brzuszne oraz inne postacie ciąż zagnieżdżających się poza prawidłowo uformowaną jamą macicy. Ciąża w rogu szczątkowym macicy to bardzo nietypowa patologia położnicza, jedna z najrzadziej występujących lokalizacji ciąży ektopowej o częstości występowania 1/76150 tys. ciąż u człowieka $[2,3,4]$. Wśród wszystkich ciąż ektopowych $0,27 \%$ lokuje się w rogu szczątkowym macicy (1/365 ciąż pozamacicznych) [2].

Celem pracy była analiza problemów, jakie wiążą się z ciążą w rogu szczątkowym macicy, dotyczących diagnostyki, rozpoznania i optymalnego leczenia z uwzględnieniem losów kobiety ciężarnej oraz jej dziecka.

\section{Omówienie}

U płodów dziewczęcych w okresie embriogenezy z nabłonka mezodermalnego dochodzi do rozwoju przewodów przyśródnerczowych Müllera. Po 6. tyg. ciąży, w toku rozwoju z górnej części przewodów Müllera rozwijają się jajowody, ze środkowej - trzon macicy, a z dolnej - szyjka macicy i górna część pochwy. U człowieka części środkowe 
i dolne przewodów przyśródnerczowych ulegają zespoleniu, tworząc pojedynczą dużą macicę, łączącą się z pojedynczą szyjką macicy, a przez nią z pochwą. Brak zespolenia prawej i lewej macicy skutkuje rozwojem macicy podwójnej-uterus didelphys. Taki stan dotyczy ok. 1 : 3000 kobiet. Agenezja jednego z przewodów przyśródnerczowch powoduje powstanie macicy jednorożnej - uterus unicornis, występującej u ok. $1: 4000$ kobiet [5]. Nieprawidłowości rozwoju embrionalnego macicy powodują różnorodne dolegliwości związane z czynnością kobiecego narządu płciowego. Należą do nich ból, zaburzenia miesiączkowania, pierwotna niepłodność, niemożność utrzymania ciąży, poronienia nawykowe, niewydolność cieśniowo-szyjkowa, poród przedwczesny, nieprawidłowości położenia i ułożenia płodu [6]. Dolegliwości wynikające z nieprawidłowości rozwoju narządów pochodzących z przewodów przyśródnerczowych są poważne, jednak w większości przypadków nie wpływają tak istotnie na zdrowie i życie ciężarnych jak ciąża w rogu szczątkowym macicy [2].

Niebezpieczeństwo tej postaci ciąży wynika z faktu, że lokuje się ona w nieprawidłowo rozwiniętym rogu macicy, który podczas rozwoju embrionalnego nie ulega zespoleniu z narządem znajdującym się po drugiej stronie linii pośrodkowej ciała. W związku z tym narząd jest hipoplastyczny, ze zmniejszonym potencjałem rozrostu doczesnej oraz myometrium w miarę rozwoju ciąży. W 75-85\% przypadków róg szczątkowy nie komunikuje się z szyjką macicy. W efekcie większość takich ciąż musi być rozwiązana za pomocą planowego zabiegu polegającego na usunięciu rogu macicy z płodem [7]. Planowy zabieg wskazywany jest jako lepszy sposób rozwiązania ciąży również w przypadku połączenia rogu macicy z jej szyjką (ryc. 1). Z tych nieprawidłowości morfologicznych macicy wynika większa skłonność do rozwoju patologii popłodu pod postacią łożyska wrośniętego i przerośniętego oraz tendencja do rozwoju spontanicznego pęknięcia macicy z następowym masywnym krwawieniem do jamy otrzewnej, skutkującym rozwojem wstrząsu hipowolemicznego, a przy braku pilnej i szybkiej interwencji chirurgicznej - nawet śmiercią ciężarnej $[4,8,9,10]$.

Taki rozwój sytuacji dominował w początku XX w. Jednym z pierwszych odnotowanych i opisanych przypadków

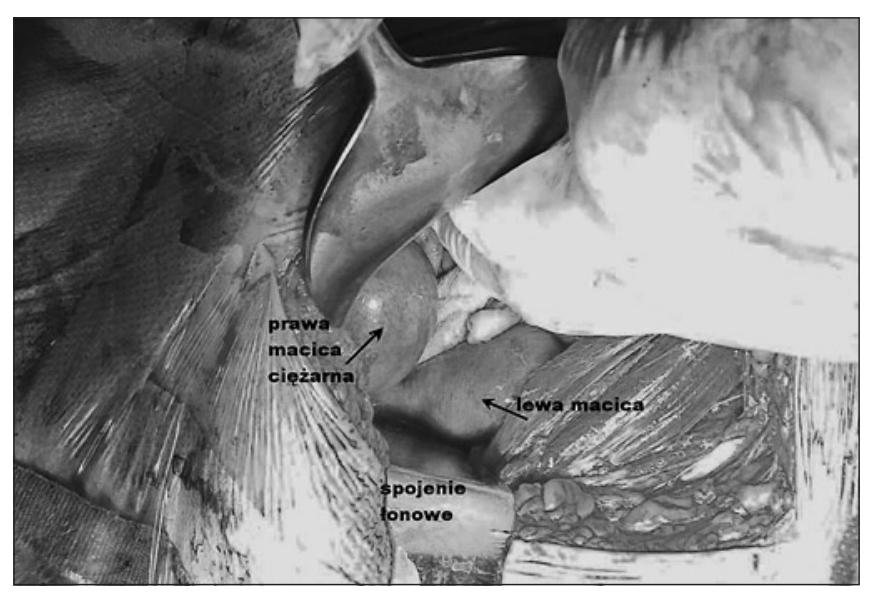

Ryc. 1. Śródoperacyjny obraz ukazujący macicę z rogiem szczątkowym po stronie prawej ciąży w rogu szczątkowym macicy jest praca Willetta z 1909 r., opisująca nagłą śmierć 19-letniej ciężarnej w ok. 19. tyg. ciąży w wyniku masywnego krwotoku do jamy otrzewnej [11]. Również w kolejnych latach umieralność kobiet w efekcie rozwoju ciąży w rogu szczątkowym macicy była wysoka - w latach 20. XX w. sięgała 23\% [2]. Rozwój technik operacyjnych oraz „medykalizacja” położnictwa połączona z rozwojem nowoczesnych technik diagnostyki obrazowej, takich jak ultrasonografia i rezonans magnetyczny, doprowadziły do znacznego ograniczenia śmiertelności wśród matek. Od ponad 50 lat, tj. od początku lat 60. XX w., na ponad 260 ciąż w rogu szczątkowym macicy opisanych w artykułach skatalogowanych w piśmiennictwie naukowym zanotowano tylko jeden przypadek śmierci ciężarnej w 2012 r., co daje wskaźnik śmiertelności wśród ciężarnych na poziomie $0,38 \%$. Ostatni odnotowany przypadek zgonu ciężarnej w 19. tyg. ciąży, rzetelnie opisany przez badaczy japońskich [4], jest bardzo pouczającym studium podkreślającym znaczenie szczegółowej, detalicznej diagnostyki ultrasonograficznej w I trymestrze ciąży, obejmującej nie tylko diagnostykę płodu, ale również identyfikację anomalii budowy narządów pochodnych z przewodów przysródnerczowych Müllera [12]. Dodatkowo szczegółowa analiza przypadku daje argumenty przeciw w dyskusji nad technikami telemedycznymi, podkreślając rolę bezpośredniego badania klinicznego w diagnostyce poważnych patologii ciążowych.

Znaczne obniżenie śmiertelności wśród ciężarnych, obserwowane od lat 60. do końca XX w., związane z wcześniejszym wykrywaniem anomalii macicy, nie wiązało się ze znaczną poprawą przeżycia płodów. Przy blisko 10-krotnym zmniejszeniu śmiertelności wśród matek w ciągu ostatniego półwiecza uzyskano wzrost przeżywalności wśród dzieci urodzonych z ciąży w rogu ektopowym macicy od ok. 6-8\% w latach 50. i 60. XX w. do 12-14\% w końcu zeszłego stulecia. Jednocześnie zmniejszył się odsetek ciąż kończonych w warunkach nagłych w związku z pęknięciem rogu szczątkowego [2, 13]. Obecnie ciąże, jeśli nie są rozpoznane wcześniej, kończone są dużo wcześniej - w III, a nawet w II trymestrze. W związku z tym średnia masa urodzeniowa dzieci żywo urodzonych w dobrym stanie klinicznym zmniejszyła się z 2100-3250 g na początku wyżej wymienionego okresu do $1770 \mathrm{~g} \mathrm{w}$ latach 90. w efekcie wcześniej planowego rozwiązania ciąży, po zakończeniu przedporodowej sterydoterapii płodów w celu poprawienia czynności układu oddechowego. Należy również wspomnieć o działaniu neuroprotekcyjnym glikokortykosteroidów. Pozytywna tendencja obserwowana jest również w XXI w. W piśmiennictwie po 2000 r. udokumentowano 13 przypadków ciąży zakończonej porodem żywego dziecka u kobiet z rogiem szczątkowym macicy, a procent żywych urodzeń w ostatniej dekadzie sięga 20.

\section{Wnioski}

Dzięki rozwojowi technik obrazowania, takich jak ultrasonografia i rezonans magnetyczny, oraz dzięki poprawieniu 
standardu tych badań możliwe jest wczesne diagnozowanie nieprawidłowości rozwoju narządów płciowych pochodzących z przewodów przyśródnerczowych Müllera.

Znacząco obniżono umieralność kobiet ciężarnych z powodu powikłań wynikających z rozwoju ciąży w rogu szczątkowym macicy, głównie przez podejmowanie wcześniejszego leczenia operacyjnego przed wystąpieniem najpoważniejszego powikłania - pęknięcia rogu szczątkowego macicy z następowym krwawieniem do jamy otrzewnej.

Poprawiono współczynnik przeżywalności noworodków poprzez ich prenatalne leczenie w celu przygotowania do przedwczesnego porodu, podejmowane przed wystąpieniem objawów klinicznych u matki. W dalszym ciągu przeżycia dzieci są incydentalne.

Wobec doskonałych efektów leczenia kobiet $\mathrm{i}$ ich dzieci należy z umiarkowanym optymizmem patrzeć na dalszą poprawę statystyk, szczególnie dotyczących przeżywalności noworodków.

\section{Piśmiennictwo}

1. Damario M., Rock J.: Ectopic pregnancy. In: The Linde's Operative Gynecology. Ed. J. Rock, H.W. Jones III. Lippincott Williams and Wilkins, Philadelphia 2008, 798-824.

2. Nahum G.G.: Rudimentary uterine horn pregnancy. The $20^{\text {th }}$-century worldwide experience of 588 cases. J Reprod Med. 2002, 47 (2), 151-163.
3. Johansen K.: Pregnancy in a rudimentary horn. Obstet Gynecol. 1983, 61, 565-567.

4. Hirose I., Harada K., Kuroda R., Ishii Y., Nakajima M., Kamei Y. et al.: An autopsy report on a ruptured rudimentary horn (uterine anomaly) with ectopic pregnancy. Forensic Sci Int. 2013, 10, 224, 1-3.

5. Moore K.L., Persaud T.V.N., Torchia M.G.: Development of the genital system. In: The developing human. Clinically Oriented Embryology. Elsevier Saunders, Philadelphia 2013, 265-281.

6. Chan Y.Y., Jayaprakasan K., Tan A., Thornton J.G., Coomarasamy A., Raine-Fenning N.J.: Reproductive outcomes in women with congenital uterine anomalies: a systematic review. Ultrasound Obstet Gynecol. 2011, 38 (4), 371-382.

7. Chopra S., Keepanasseril A., Rohilla M., Bagga R., Kalra J., Jain V.: Obstetric morbidity and the diagnostic dilemma in pregnancy in rudimentary horn: retrospective analysis. Arch Gynecol Obstet. 2009, 280 (6), 907-910.

8. Henriet E., Roman H., Zanati J., Lebreton B., Sabourin J.C., Loic M.: Pregnant noncommunicating rudimentary uterine horn with placenta percreta. JSLS. 2008, 12 (1), 101-103.

9. Baughn M.R., Vaux K., Masliah E.: Placenta accreta in a separate uterine horn. Pediatr Dev Pathol. 2010, 13 (1), 63-65.

10. Banaś T., Mosur K., Banaś B., Pityńska-Korab E., Nawara A.: Ciąża w niekomunikującym rogu szczątkowym macicy - opis dwóch przypadków. Perinatologia Neonatologia I Ginekologia. 2008, 1 (2), 157-160.

11. Willett A.: Pregnancy in a Rudimentary Horn of a Bicornate Uterus. Proc R Soc Med. 1909, 2, 342-344.

12. Spaczyński R.Z., Pietryga M.: Wrodzone wady macicy. In: Praktyczna ultrasonografia w położnictwie i ginekologii. Ed. Pietryga M., Brązert J. Wyd. Exemplum, Poznań 2012, 775-786.

13. Siwatch S., Mehra R., Pandher D.K., Huria A.: Rudimentary horn pregnancy: a 10-year experience and review of literature. Arch Gynecol Obstet. 2013, 287 (4), 68-695. 